\title{
Continuous Assessment in ESP Context
}

\author{
Iryna Didenko \\ Taras Shevchenko National University, Kyiv, Ukraine \\ Olena Filatova
}

Taras Shevchenko National University, Kyiv, Ukraine

\begin{abstract}
Due to the globalization process and scarcity of learning hours Ukrainian higher educational standards in terms of English for Specific Purposes course are being reconsidered currently to enable university graduates to be highly competitive in the world labour market. Under these conditions assessment as an integrated part of any process of learning has to be reviewed as well. Earlier assessment was used as a tool for increasing extrinsic motivation of students and measuring their success, but nowadays, when the learning hours have been decreased dramatically, we have researched, how to reduce possible demotivating effect of assessment and how to use assessment for enhancing intrinsic motivation of students. For that purpose we have used a variety of continuous assessment. Moreover, we have managed to contribute in the development of 21-st century skills of our students (critical thinking, creative thinking, collaborating, communicating) through self-assessment and peer-assessment while they were developing the criteria for assessment themselves. Furthermore, during the experiment that lasted from September, 2016 till June, 2017 students under our supervision have developed the lists of criteria for assessing such soft skills as presenation preparation and delivery, participation in discussions, etc. The results of the experiment were measured with the help of summative assessment at the end of the study year and questionnaires that students under experiment filled in January, 2017 and in June, 2017. The difference with the control group was tremendous.
\end{abstract}

Keywords: continuous assessment, peer-assessment, self-assessment, formative assessment, summative assessment, $21^{\text {st }}$ century skills, soft skills, intrinsic motivation, English for Specific Purposes

\section{Introduction}

Under the process of crutial transformation of higher educational standards that is going on in Ukraine we can not help considering such an integrated part of any learning process as assessment. There is a great variety of definitions what assessment is. T.Dary Erwin identifies assessment as: 'the systematic basis for making inferences about the learning and development of students. It is the process of defining, selecting, designing, collecting, analyzing, interpreting, and using information to increase students' learning and development' (Erwin, 1991). Catherine A. Palomba and Trudy W. Banta determine assessment as: 'the systematic collection, review, and use of information about educational programs undertaken for the purpose of improving student learning and development' (Palomba and Banta, 1999). Mary E. Huba and Jann E. Freed define assessment as: 'the process of gathering and discussing information from multiple and diverse sources in order to develop a deep understanding of what students know, understand, and can do with their knowledge as a result of their educational experiences; the process culminates when assessment results are used to improve subsequent learning' (Huba and Freed, 2000). Mary J. Allen thinks that 'assessment involves the use of empirical data on student learning to refine programs and improve student learning' (Allen, 2007).

Mostly all of these definitions are more or less similar, but for current Ukrainian tertiary education in general and for English for Specific Purposes course in particular the most relevant and up-to-date definitions of assessment are given in Common European Framework of Reference for Languages: Learning, Teaching, Assessment (CEFR, 2011) and by Tony DudleyEvans and Maggie Jo St.John (Dudley-Evans and St.John, 2012). Tony Dudley-Evans and Maggie Jo St. John say that assessment is a part of evaluation and is not limited only to formal measuring process (tests), but includes 'less formal, 
more qualitative methods' that give 'feedback on learning' (Dudley-Evans and St.John, 2012). Common European Framework of Reference for Languages: Learning, Teaching, Assessment implies assessment as evaluation of not only language proficiency, but the effectiveness of materials and methods used by the teacher, learners' satisfaction, etc (CEFR, 2011). Furthermore, they introduce different types of assessment: continuous assessment, formative and summative assessment, checklist rating, assessment by others, self-assessment, etc (CEFR, 2011). Continuous assessment is integrated in the course assessment, 'which contributes in cumulative way to the assessment at the end of the course' (CEFR, 2011). According to Dudley-Evans and Maggie Jo St.John continuous assessment is more flexible, can be done during some period of time by the teacher, the learner him/herself or by peers, moreover, learners can use different resources to complete their work (Dudley-Evans and St.John, 2012).

We think that continuous assessment is crucially important especially in English for Specific Purposes course, because it does not only give feedback from teacher to student, student to teacher, student to student that certainly leads to learning improvement, but develops intrinsic motivation of learners, their autonomy and prepares them to function effectively in their future professional situations. Moreover, we have researched how self-assessment and peer-assessment can improve the final performance of the learners.

\section{Methods}

The main method used was experimental research. Two groups (control and experimental) of $1^{\text {st }}$ year students majoring in International Economics participated in the experiment. Each group consisted of 12 people of approximately the same initial level of language proficiency. The experiment lasted from September, 2016 till June, 2017 and finished with summative assessment in June, 2017. The students of the experimental group were deeply involved in developing the criteria for assessment, in the process of self-assesment and peer-assessment according to the criteria. Furthermore, they were asked to analyse the effectiveness, objectivity and influence of such type of assessment on students' intrinsic motivation enhancement. For this analysis preliminary, interim and closing questionnaires were used during the experiment, where students expressed their attitude to such approach to assessment and changes in their intrinsic motivation. The experiment during the whole academic year gave an opportunity to analyse and compare the progress the students from experimental group and from the control group had made.

\section{Results}

Before we start describing the results it is important to outline the scheme of scores accumulation during the semester. At the end of each semester the $1^{\text {st }}$ year students could get 100 points in total: during the first and the second modules - 40 points, for their self study - 40 points, as well and 20 points - for their final test. In terms of preparation of future professionals self-study can be considered as one of the most important parts of this preparation. Self-study gives the students certain amount of autonomy, helps them to develop such skills as critical thinking, creative thinking, collaborating, communicating, considered as 21-st century skills, skills that are seeked by employers in ther potential employees. So our students due to self-study are getting competitive advantage in the labour market. That is why assessment of such kind of study attains more and more weight. We have studied how assessment could be not only objective, but also motivating.

One of the forms of reporting the results of students' self-study findings is presentation. It should be mentioned, that presentation skill is one of the most important skill that employers of the 21st century will expect from their future employees, who are currently our students. That is why the purpose of our research was to check how to assess it adequately and enhance students' intrinsic motivation in the same time. Teacher together with students during the learning, how to prepare and deliver a successful presentation simultaneously creates a number of criteria, according to which their presentation is going to be assessed. Then with the help of online tool for creating rubrics - Rubistar (Rubistar), we range the number of points the students can get for meeting this or that criteria.

For example, for oral presentation we have used the following rubric (Adapted from Rubistar):

\begin{tabular}{|l|l|l|l|}
\hline Category & 2 & 1 & 0 \\
\hline 1. Vocabulary & Uses extensive and & Uses rather extensive vocabulary, & Uses not extensive \\
& appropriate vocabulary. & but sometimes inappropriately. \\
& Extends audience vocabulary & Includes 1-2 words that might be & \\
& by defining words that might & new to most of the audience, but \\
be new to most of the & does not define them. & \\
\hline
\end{tabular}




\begin{tabular}{|c|c|c|c|}
\hline & audience. & & \\
\hline 2. Content & $\begin{array}{l}\text { Shows a full understanding of } \\
\text { the topic and achieves target } \\
\text { audience's attention. }\end{array}$ & $\begin{array}{l}\text { Shows a good understanding of the } \\
\text { topic, but sometimes fails in } \\
\text { achieving target audience's } \\
\text { attention. }\end{array}$ & $\begin{array}{l}\text { Does not seem to understand } \\
\text { the topic very well. }\end{array}$ \\
\hline 3. Preparedness & $\begin{array}{l}\text { Student is completely } \\
\text { prepared and has obviously } \\
\text { rehearsed. }\end{array}$ & $\begin{array}{l}\text { Student seems pretty prepared but } \\
\text { might have needed a couple more } \\
\text { rehearsals. }\end{array}$ & $\begin{array}{l}\text { Student does not seem at all } \\
\text { prepared to present. }\end{array}$ \\
\hline 4. Speakes clearly & $\begin{array}{l}\text { Speaks clearly and distinctly } \\
\text { all (100-95\%) the time, and } \\
\text { mispronounces no words. }\end{array}$ & $\begin{array}{l}\text { Speaks clearly and distinctly most } \\
(94-85 \%) \text { the time, but } \\
\text { mispronounces } 2-3 \text { words. }\end{array}$ & $\begin{array}{l}\text { Often mumbles or can not be } \\
\text { understood or mispronounces } \\
\text { more than 2-3 words. }\end{array}$ \\
\hline $\begin{array}{l}\text { 5. Posture and eye } \\
\text { contact }\end{array}$ & $\begin{array}{l}\text { Stands up straight, looks } \\
\text { relaxed and confident. } \\
\text { Establishes eye contact with } \\
\text { everyone in the room during } \\
\text { the presentation. }\end{array}$ & $\begin{array}{l}\text { Sometimes stands up straight and } \\
\text { establishes eye contact. }\end{array}$ & $\begin{array}{l}\text { Slouches and/or does not } \\
\text { look at people during the } \\
\text { presentation. }\end{array}$ \\
\hline 6. Volume & $\begin{array}{l}\text { Volume is loud enough to be } \\
\text { heard by all audience } \\
\text { members throughout the } \\
\text { presentation. }\end{array}$ & $\begin{array}{l}\text { Volume is loud enough to be heard } \\
\text { by all audience members at least } \\
80 \% \text { of the time. }\end{array}$ & $\begin{array}{l}\text { Volume often too soft to be } \\
\text { heard by all audience } \\
\text { members. }\end{array}$ \\
\hline $\begin{array}{l}\text { 7. Collaboration with } \\
\text { peers }\end{array}$ & $\begin{array}{l}\text { Almost always listens to, } \\
\text { shares with, and supports the } \\
\text { efforts of others in the group. } \\
\text { Tries to keep people working } \\
\text { well together. }\end{array}$ & $\begin{array}{l}\text { Often listens to, shares with, and } \\
\text { supports the efforts of others in the } \\
\text { group but sometimes is not a good } \\
\text { team member. }\end{array}$ & $\begin{array}{l}\text { Rarely listens to, shares with, } \\
\text { and supports the efforts of } \\
\text { others in the group. Often is } \\
\text { not a good team member. }\end{array}$ \\
\hline 8. Pitch & $\begin{array}{l}\text { Pitch was often used and it } \\
\text { conveyed emotions } \\
\text { appropriately. }\end{array}$ & $\begin{array}{l}\text { Pitch was often used but the } \\
\text { emotion it conveyed sometimes did } \\
\text { not fit the content. }\end{array}$ & $\begin{array}{l}\text { Pitch was not used to convey } \\
\text { emotion. }\end{array}$ \\
\hline 9. Comprehension & $\begin{array}{l}\text { Student is able to accurately } \\
\text { answer almost all questions } \\
\text { posed by classmates about } \\
\text { the topic. }\end{array}$ & $\begin{array}{l}\text { Student is able to accurately answer } \\
\text { a few questions posed by } \\
\text { classmates about the topic. }\end{array}$ & $\begin{array}{l}\text { Student is unable to } \\
\text { accurately answer questions } \\
\text { posed by classmates about } \\
\text { the topic. }\end{array}$ \\
\hline 10. Time limit & $\begin{array}{l}\text { Presentation is } 5-6 \text { minutes } \\
\text { long. }\end{array}$ & Presentation is $3-4$ minutes long. & $\begin{array}{l}\text { Presentation is less than } 3 \\
\text { minutes or more than } 6 \\
\text { minutes. }\end{array}$ \\
\hline
\end{tabular}

After the presentation students, who were delivering it, reflect on themselves according to the criteria from this rubric: what went well, what they would change next time, what are their areas for development. Before their reflecton, their peers assess them in written form according to the check-list with the criteria (maximum - 20 points), as well as the teacher assesses the presentation according to the same check-list (maximum - 20 points). After the reflection session, peers and the teacher comment the same areas in turn. The final grade (maximum - 40 points) consists of average peers' amount of points (maximum 20) and teacher's grade (maximum 20).

The advantages of such system of presentation assessment are as follows:

When students participate in choosing the criteria they are going to be assessed to, they automatically keep these criteria in mind, when they are preparing to the presentation. This ensures deeper processing of the material, more serious attitude to the task performing and enhancement of students' intrinsic motivation. They mentioned this in their questionnaires.

Three levels of assessment: self-assessment, peer-assessment and teacher assessment lead to profound analysis of the achievements and areas for development by the students themselves. And on this stage some psychological factors are working: if people themselves perceive their progress and mistakes (it is not their teacher, who tells them that they have made a mistake), they subconsciously will not deny them and will try to correct these mistakes. And again due to this effect we can speak about intrinsic motivation.

But, unfortunately, in this system there could be some disadvantages: 
For example, validity of such grades is rather disputable. On the one hand, the assessment is measured due to the criteria, but, on the other hand, a half of the grade is given by peers. And that is the question of validity of this part of the grade. To our opinion and according to the results of the experiment the final results coincided teacher's view that means that if the teacher had been the only assessor, the results would be the same. But this problem needs more research and experimenting.

One more challenge is objectivity. Haman factor is something that we have to take into consideration. Peers are not professional assessors; they are not bound to be objective. This is a matter of their social responsibility and integrity. It may happen that they increase the amount of points, because they are friends with the presenter, or vice versa, decrease grades of their enemy. During our experiment, in order to avoid subjectivity, we removed one the highest and one the lowest grade, it was done transparently: students knew about the procedure of calculation in advance. But still unfair assessment may happen, because one student may have more than one friend or more than one enemy.

\section{Conclusions}

The experiment has shown that continuous formative and summative assessments can not only serve as 'stick and carrot', but be extremely motivating for students. It does not only give feedback from teacher to student, student to teacher, student to student that certainly leads to learning improvement, but develops intrinsic motivation of learners, their autonomy and prepares them to function effectively in their future professional situations, that is why we believe that continuous assessment is crucially important especially in English for Specific Purposes course. Moreover, we found out how selfassessment and peer-assessment can improve the final performance of the learners. The experimental group gained average grade of $37.5(84 \%)$, when the control group's average grade was $33.5(94 \%)$, so the results of the group under experiment are $10 \%$ higher, than the results of the control group. Both the final results and the feedbacks of the students have proved the relevance of such system of assessment to the ESP context. In spite of some disadvantages this variety of assessment is worth using in ESP classroom.

\section{References}

[1] Allen, M. J. (2007). Assessing Academic Programs in Higher Education. John Wiley \& Sons.

[2] Assessment. (2011). In Common European framework of reference for languages: learning, teaching, assessment (pp. 177-196). Cambridge: Cambridge University Press.

[3] Dudley-Evans, T., \& Jo, S. J. (2012). Assessment: Continuous assessment and testing. In Developments in English for specific purposes (pp. 210-229). Cambridge: Cambridge University Press ELT.

[4] Erwin, T. D. (1991). Assessing Student Learning and Development: A Guide to the Principles, Goals, and Methods of Determining College Outcomes. Jossey-Bass .

[5] Huba, M. E., \& Freed, J. E. (2000). Learner-centered assessment on college campuses: shifting the focus from teaching to learning. Boston: Allyn and Bacon.

[6] Palomba, C. A., \& Banta, T. W. (1999). Assessment essentials: planning, implementing, and improving assessment in higher education. San Francisco: Jossey-Bass .

[7] Rubistar: Create Rubrics for your Project-Based Learning Activities http://rubistar.4teachers.org/index.php?screen=NewRubric

[8] Common European framework of reference for languages: learning, teaching, assessment. (2011). Cambridge: Cambridge University Press. http://www.coe.int/t/dg4/linguistic/Source/Framework_EN.pdf 